DOI 10.7764/ijanr.v47i3.2299

\title{
REVIEW \\ Advancing food sovereignty through farmer-driven digital agroecology
}

\author{
Hannah Wittman, Dana James, and Zia Mehrabi \\ University of British Columbia, Institute for Resources, Environment and Sustainability. 2357 Main Mall, \\ Vancouver, British Columbia, Canada.
}

\begin{abstract}
H. Wittman, D. James, and Z. Mehrabi. 2020. Advancing food sovereignty through farmerdriven digital agroecology. Int. J. Agric. Nat. Resour. 235-248. Agroecology, as a science, practice, and social movement, has been posed as a potential pathway to revitalize global food systems through a shift towards social and ecological justice. Complex and diversified agroecological systems vary widely globally and have been poorly characterized by traditional agronomic assessments that often focus narrowly on income and yield over other socioecological dimensions such as farmer and worker well-being, dietary diversity, environmental impacts and biodiversity conservation. In response, we propose an approach to the digital monitoring and assessment of agroecological practices that acknowledges and respects diverse contexts and improves power dynamics by centering the agency and biocultural knowledge of diverse farmers and communities. We describe a community-university partnership designed to develop a farmer-driven, open-access, and open-source digital tool for agroecological monitoring and certification. The farmer-scientist research team aims to chart a course for researchers to investigate how trade-offs among productive, sociocultural, economic, and/or environmental indicators might be minimized to enhance overall system sustainability across diverse contexts globally while also providing tools of use to agroecological farmers and their organizations, who can then autonomously capture (some of) the benefits of the digital agricultural revolution without ceding data sovereignty.
\end{abstract}

Keywords: Agroecological transition, citizen science, data science, digitalization, participatory action research, sustainable food systems.

\section{Introduction}

Decades after the Green Revolution, almost two billion people worldwide are malnourished, and agriculture is one of the greatest drivers of anthropogenic climate change and biodiversity loss (Foley et al., 2012; EAT-Lancet, 2019). Tra-

Received Oct 27, 2020. Accepted Dec 02, 2020.

Corresponding author: hannah.wittman@ubc.ca ditional farming communities are threatened by the encroachment of large-scale, input-intensive agriculture, and young people are increasingly leaving the sector due to the challenges of providing economically viable and ecologically healthy livelihoods for their families. The concentration and globalization of the global agricultural input industry and markets, along with deregulation associated with agricultural trade agreements, have constrained farmer decision-making, creating 
"new ethical challenges" for farmers responsible for stewarding the globe's agricultural landscapes (Hendrickson \& James, 2005).

In response, farmers, agricultural social movements, consumers, researchers, and policymakers are seeking agroecological alternatives that can improve sociocultural, economic, and environmental outcomes by reducing the use of synthetic inputs, rebuilding local food systems based on socially mediated markets, and working with nature instead of attempting to overcome it (Perfecto \& Vandermeer, 2010). Agroecology is defined as the application of ecological principles to the design of agricultural systems in a way that acknowledges and respects diverse contexts and addresses power dynamics by centering the agency and biocultural knowledge of farmers and communities. As a science, practice, and social movement, agroecology has been put forth as a promising pathway for transitioning to more sustainable, resilient, and just agri-food systems (Altieri, 1995; Kremen et al., 2012; FAO, 2018a, 2018b; HLPE, 2019).

However, several challenges persist in scaling out agroecology, not least of which is the difficulty in documenting, evaluating, and supporting the diverse range of practices that characterize agroecological systems. This essay explores the potential of and challenges related to the digitalization of agroecological systems and provides an example of a farmer-scientist partnership based on the principles of food sovereignty to develop an open-access digital tool for participatory agroecological certification.

\section{Challenges in making agroecological practices "legible" in agricultural assessment frameworks}

Assessing agroecological systems at large scales is challenging. To date, most efforts to operationally monitor and evaluate the multidimensional outcomes of agricultural systems have been limited in scope, either focusing on a narrow geographic region or on a small number of variables associated with a particular agricultural production process (Duru, Therond \& Fares, 2015; Sampson, 2018). Research on the performance of farm-level interventions also tends to privilege yield and production metrics over other socioecological dimensions, such as farmer livelihoods or well-being (cf. Ricciardi et al., 2020). There is therefore a need to systematically assess synergies and trade-offs across the multiple services and outcomes provided by agricultural landscapes (c.f. D'Annolfo et al., 2017; Wittman et al., 2017; Ramankutty et al., 2019). Beyond food production, these include social, cultural, and other ecosystem services that affect sustainability, well-being, and food sovereignty (Ruiz-Almeida \& Rivera-Ferre, 2019).

Current platforms for assessing agricultural performance at the global scale, such as the FAO World Program for the Census of Agriculture, are based on data collected sporadically over long time frames (e.g., once every decade) and often do not meaningfully involve farmers or traditional knowledge keepers in the process (Pretty, 2018). Census survey rosters associated with the World Census of Agriculture, for example, do not include questions that could more accurately identify the diverse array of context-specific management practices present across global agroecological systems (cf. FAO, 2015). In recognition of this gap, the FAO has developed new recommendations for country-led agricultural and rural statistics development, including piloting new survey questionnaires in Africa and the Asia-Pacific regions that address aspects of the Sustainable Development Goals as well as additional questions appropriate to more diverse production systems (AGRIS, n.d.). The FAO has also led the development of a new survey tool for the assessment of agroecological performance (TAPE) in response to growing political interest in agroecology in relation to the SDGs (FAO, 2019). Other global platforms, such as GEOGLAM, involve a more frequent collection of remote sensing-derived data on agricultural systems but are limited in system 
coverage (major crops) and often lack data on context-specific social, political, and ecological processes associated with observable outcomes.

On the other side of the methodological spectrum, ethnographies and case studies adopting methods from the social sciences have often been used to study agroecology and to account for context specificity at the community and regional levels (Pimbert, 2018). Although generalized knowledge claims can be made from case studies of agroecological systems (c.f. Magliocca et al., 2018), most case studies are not designed for comparison or monitoring over time. To this end, researchers have developed several sophisticated and interdisciplinary agricultural sustainability assessment tools that can be used in multiple contexts, such as the process-driven MESMIS Indicator-based Sustainability Assessment Framework (Astier et al., 2012) (which formed the basis of the FAO's TAPE tool discussed above) and the "Response-Inducing Sustainability Evaluation" (RISE) framework (which is based on a standard set of indicators) (Grenz et al., 2016). However, the application of these frameworks can also be time consuming and costly for both researchers and farmers - particularly for farmer networks or communities who find themselves frequently fielding research requests. Lastly, while case studies and the indicator-based approaches described above have gleaned important insights for researchers and include various degrees of farmer participation, the final results are often not returned to farmers at all or are of limited direct use to farmers.

In summary, very few of the tools described above are accessible to farmers themselves to use autonomously in the documentation and assessment of their own management practices. The "digitalization" of agriculture and the approach of human-centered design provide a potential pathway through which to ensure that farm-level data and assessments are co-created with farmers and that the results both originate and stay in the hands of the farmers themselves.

\section{Digital agroecology: a way to bridge the data gap?}

Digital agriculture, a core feature of the "Fourth Industrial Revolution" or of Agriculture 4.0, involves a suite of new technologies that are expected to transform agriculture over the coming decades, including those that create and use big data; employ machine learning, deep learning, remote sensing, robotics and autonomous systems; build on expanded access to mobile devices and social media; and integrate bundled services for farmers (Trendov et al., 2019; Rotz et al., 2019). One rapidly growing area of digital agriculture is the idea of "smart farms," which seek to reduce labor constraints and make farming operations more predictable, streamlined, safe and profitable by collecting and analyzing large quantities of data. These data can be derived from yield monitors and sensors connected to seeding, fertilizing, irrigation, harvesting equipment, milking stations, livestock housing, and storage units. Smart farms also access advanced weather and market information systems, which can be used alongside robotics for high levels of automation in certain farm management operations. By 2025, farms in industrialized countries using smart farm technologies are expected to produce millions of data points each day (Howard, 2019).

While many digital agriculture technologies have primarily been marketed to large-scale and industrial farms, others have been designed for use by small-scale farmers (e.g., Srinivasan, 1999; Shibusawa, 2001; Van Loon et al., 2018). For example, social enterprises, such as Precision Agriculture for Development (PAD), have emerged and primarily targeted smallholders in Africa and Asia (e.g., Mitchell, 2018). Despite the massive existing global "digital divide" in access to digital infrastructure, a broad range of community-, government-, and NGO-driven initiatives have emerged to utilize new digital technologies to design and deliver data-driven farming advisory services (such as digital extension, climate services, market information, and 
access to finance) to small-scale farmers (Trendov et al., 2019; Mehrabi et al., 2020).

Food sovereignty and peasant farm networks have also discussed the potential benefits of engagement with digital tools in the food system:

Proponents of digitalization emphasize the supposed benefits for marginalized people and small-scale food producers: digitalized land administration will increase tenure security; satellite-supported allocation of fishing rights will ensure transparency and security for small-scale fishers; blockchains will link producers to consumers directly, eliminating exploitation by intermediaries; digital agriculture will reduce input costs and increase the efficiency of irrigation and production. E-commerce is widely touted as the gateway for creating new markets and ways of marketing agricultural products (Nyéléni Forum for Food Sovereignty, 2019).

These same food sovereignty advocates express concerns, however, that "the technology and infrastructure for this rosy scenario will come from corporations, who are in it for profits, not public benefit" (NFFS, 2019). Even proponents of the technology have pointed out the possibility of "data rich, information poor" (DRIP) conundrums:

Forthcoming protocols and algorithms will help farmers distill big data into actionable events. But the technology's current reporting (without agronomic interpretation) isn't meaningful to most growers. Data analysis isn't something most have the time or training to navigate. An interpreter is needed to translate the rendered data into confident action (Howard, 2019).

These concerns are valid. Agribusiness giants have developed proprietary software capable of interpreting farm data and providing data-driven management analytics and solutions for farmers using their hardware and software, filling the void left by the gutting of public extension and agronomic advisory services across the globe. Following a global trend of the consolidation of resources and power within the global food system, power relations associated with the digital agriculture revolution have propelled further digital, economic, and agronomic divides within and between agri-food supply chains.

As a result, the digital, material, and political exclusion of smallholder farmers has served to obscure the creative contributions of the globally diverse food sovereignty movement - some 200 million peasant, Indigenous, and fisher families - to food systems. At the same time, we know that smallholders ( $<2$ ha) produce $30-34 \%$ of the global food supply in $24 \%$ of the gross agricultural area, and these farming systems demonstrate more crop diversity and lower rates of postharvest loss (Ricciardi et al., 2018). There is global consensus, as affirmed by the UN Committee on World Food Security's High-Level Panel of Experts, on the need for transdisciplinary collaborations to "develop practical, scientifically grounded and comprehensive performance metrics and indicators of agriculture and food systems as a basis for assessment, policy implementation, and investment decisions" (HLPE, 2019). These must be co-created and co-designed with, for, and by farmers and land stewards.

Pat Mooney, an active proponent of "wide-tech" within the food sovereignty movement, notes that farmers are constantly exchanging production and research information and using digital technology, combined with their own practical experience, to engage in their own forms of research and knowledge exchange. He suggests that:

Iflab-based scientists and field-based farmers can combine high tech with wide tech, smallholder producers may be able to take on some of the new technologies with confidence, and could adapt some of the latest information technologies to assess and access new innovations that will ensure there is good food, fairly produced, 
on the table in 2050. The real challenge will be to establish a respectful relationship in which scientists do not see farmers as either cheap labor or experimental subjects, but as the best judges of their own needs - and the best placed to determine their own opportunities (Mooney, 2018).

\section{Citizen science: data-driven agroecology from the ground up}

As food sovereignty scholars, we are called to codesign, practice, and disseminate a wide range of research methods to make diverse, equitable, and sustainable agroecological landscapes more legible (i.e., more easily understood across disciplinary, community, and policy spaces). One way forward involves taking seriously the idea of citizen science based on the premise of epistemological pluralism: that is, science conducted in the public interest, using a wide range of positionalities, approaches, and methods, in collaboration with grassroots social actors, and with the intention to influence policy towards supporting more sustainable food system processes and outcomes. Citizen science is increasingly recognized as a tool capable of addressing many "grand challenges" facing food systems and as a potentially transformative means to reconnect farming communities with extension and outreach programs (Ryan et al., 2018).

Citizen science can take more extractive or emancipatory forms (Kimura \& Kinchy, 2019). Both forms of research can benefit farmers, and on-farm research trials with varying degrees of farmer participation in research design and implementation have been utilized by agronomic and ecological researchers for decades. On one end of the spectrum, farmers and other citizen volunteers are involved in the "crowdsourcing" of data with focuses as diverse as bird counts, climate change impacts, crop variety performance, crop functional traits, and pest outbreaks (cf. van Etten et al., 2019; Isaac \& Martin, 2019). Steinke, van Etten \& Zelan (2017) tested the accuracy of farmer-generated data in agricultural citizen science and suggested that while the reliability of farmers' experimental observations has generally been low, aggregate validity has been achieved with higher numbers of observers through what the authors deem the "Wisdom of Crowds" principle in agricultural research.

On the other end of the spectrum, farmer-led and participatory approaches to the cocreation of research place farmers at the forefront, from the establishment of research questions to every aspect of research design, data collection, analysis, and application. For example, Bezner Kerr et al. (2019) describe a participatory research project applied in Malawi through which 425 farm households carried out agroecological experiments of their own choosing over a four-year period. The project resulted in significant increases in intercropping and legume diversification; the addition of compost, manure and crop residue amendments; and improvements in food security and dietary diversity, health, and well-being.

Mendez et al. (2017) synthesize several factors that reflect effective participatory action research (PAR), or "science for the people," related to agroecological processes:

(1) farmer/stakeholder participation in setting the research agenda from the outset, resulting in higher engagement and enhanced outcomes;

(2) employment of the right partners for the desired outcomes;

(3) intentional and explicit reflection; and

(4) cross-generational collaborations crucial to long-term benefits

Pretty et al. (2020) documented the establishment of over eight million new social networks, farmer federations, and rural cooperatives focused on supporting transitions to equity and sustainability, covering 
170-255 million group members working over 300 million hectares of land, $98 \%$ of which is located in developing countries. These food and farming systems represent extensive diversity in landscape management, biodiversity conservation, market structures, and the use of agroecological practices. In addition to their role in identifying research and knowledge pathways, decentralized agroecological transition networks involved in participatory action research are providing a way forward in connecting the need for better decision-making support at the local level to global conversations on evidencebased policy change towards the development of sustainable food systems.

Integrating the diverse knowledge and perspectives present in the global context is crucial to the field of agroecology, which aims to combine scientific and citizen knowledge and values in mutually beneficial exchanges based on reciprocity (Brem-Wilson, 2015; Mendez et al., 2015; Gliessman, 2016). Citizen science approaches to documenting and assessing agroecological transitions have been proposed as a pathway that is inclusive of digital agriculture while recognizing the importance of farmer-driven participatory action research and the cocreation of knowledge that respects data sovereignty. This idea, alongside Indigenous frameworks for data Ownership, Control, Access and Possession (OCAP ${ }^{\mathrm{TM}}$, FNIGC 2014), can form the basis of an equitable data governance framework under which farmers and Indigenous peoples have control over data generation, storage, ownership, and access and over decision-making processes influenced by these data (see Kukutai \& Taylor, 2016).

The global food sovereignty movement has also emphasized the need to better understand the potential implications of digital technologies for food security, ecological sustainability, equity, and governance in food systems. The Nyéléni Forum on Food Sovereignty, for example, has posed the following questions for both social movements and researchers interested in projects related to digital agroecology, asking participants to consider: 1. Who are the actors developing digital
technologies and for what purposes?

2. Who has access to and control over digital technologies and for what purposes?

3. Who owns the huge amount of data that is created everyday by all of us, and who has the right to use and draw economic benefit from it?

4. How should the applications and impacts of digital technologies be monitored and assessed? How should these technologies be governed and regulated for the public good?

5. How should the risks deriving from digital technologies be assessed, and their application be monitored?

6. How can we challenge the dominant narrative that equates innovation with technology, to underline and promote peasant and indigenous innovations, practices and knowledge?

7. What are the relationships between peasant and indigenous innovations, practices and knowledge, and digital technologies?

8. How can we use digital technologies to advance food sovereignty and agroecology? With what kinds of technologies, under what conditions and how should they be governed?(Nyéléni Forum for Food Sovereignty, 2019).

In a reflection focused on the digitalization of agriculture for IAASTD+10, Hilbeck and Tiselli (2020) suggest that digitalization can be "compatible with and support agroecological farming" but only when using an "entirely different approach from the one currently applied by actors in conventional agriculture." The authors suggest that digital agroecology must not be a one-sizefits-all tool but rather enable the integration of 
diversity and context sensitivity, adaptability, and interoperability. Instead of using

algorithms [to] mine and process large quantities of data related to and extracted from farming operations, to finally deliver statistical indicators which may or may not agree with a farmer's knowledge or experience and offer single (input) recipe solutions... [digital agroecological tools must] harmonize bottom-up (farmers to experts), top-down (experts to farmers) and horizontal (peer to peer) modes of communication, co-production, and dissemination of knowledge... [where] farmers are fully recognized as originators and co-creators of knowledge (Hilbeck and Tiselli, 2020).

As such, digitalization must respect the social and cultural processes associated with agriculture rather than assuming that all farm work is characterized by "drudgery and hardship." Digitalization must also acknowledge and appreciate all dimensions and outcomes, including the delights, well-being and power that working in food systems can provide to participants. This entails ensuring that farmers are at the forefront of designing digital tools that work for them and that respect local cultural contexts and conditions. In the following sections, we discuss one such experiment.

\section{Digital Agroecological Certification: a pathway to scaling agroecology?}

Beginning in the 1970s, the certification of "sustainable" agricultural practices - variously known as "natural," "organic," "fair trade," etc. - emerged from local and grassroots networks, with standards developed and monitored by farmers themselves through grounded forms of peer review combined with education and extension work related to sustainable agriculture.

Globally, organic certification has risen exponentially, comprising one of the world's fastest-growing food sectors (Seufert, Ramankutty \& Mayerhofer, 2017). As organic food production has expanded and entered global trade networks, the model increasingly relies on third-party certification. The transaction costs and detailed record keeping associated with third-party certification have highlighted the inaccessibility of third-party certification to many global small-scale farmers (Nelson et al., 2009). There has also been critique of organic agriculture as having devolved into an input-substitution model of agriculture removed from its roots.

In response, participatory and farmer-to-farmer certification systems have reemerged as a movement "beyond organic" that attends more closely to the root values of agroecology. Participatory guarantee systems (PGSs), as codified by the International Federation of Organic Agriculture Movements (IFOAM) in 2008, are "locally focused quality assurance systems. They certify producers based on active participation of stakeholders and are built on a foundation of trust, social networks and knowledge exchange." PGSs can be recognized by governments but require local food consumers and growers to agree on the "conditions of their local food systems and the ways these are verified... including the choice and definition of the standards, the development and implementation of verification procedures, and the review and decision process to recognize farmers as organic" (IFOAM, 2018).

In the late 1990s and early 2000s, the PGS movement began to gain global recognition, particularly in Latin America, with the first international workshop on PGSs organized in Brazil by the International Federation of Organic Agriculture Movements (IFOAM) and Latin American and Caribbean Agroecological Movement. In 2019, the IFOAM estimated that there are now more than 220 PGS initiatives in 76 countries, involving 567,142 farmers (IFOAM, 2019). These initiatives apply a number of core principles that align with food sovereignty and agroecology movements: trust, transparency, participation, and learning. Participatory guarantee systems also often involve food consumers both in the certification process 
and in building market networks in urban centers, helping to bridge the rural-urban divide and engage urban citizens more effectively in the food sovereignty movement (Bowness \& Wittman, 2020). Finally, as the IFOAM itself points out, unlike global third-party organic certification, which seeks to uphold a limited set of globally applicable standards, a PGS is not a "one-sizefits all" approach to agriculture. Instead, a PGS is inclusive of diverse processes and indicators that are appropriate based on the sociocultural, economic, and ecological context (IFOAM, 2019).

\section{Supporting agroecological transitions through participatory action research}

Beginning in 2015, researchers from the University of British Columbia and the University of Michigan were invited to work with Brazilian nongovernmental organizations (NGOs) Centro de Estudos e Promoção da Agricultura de Grupo (CEPAGRO) and Centro Vianei, community organizations working in southern Brazil to advance the movement and practice of agroecology. The organizations sought support for the development of a socioecological evaluation framework to assess the efficacy of food system interventions that they were implementing at the time - including participatory agroecological certification and farm-to-institution public procurement programs - in enabling progress towards food sovereignty (Guerra et al., 2017; Wittman \& Blesh, 2017).

A key finding of this project was that knowledge mobilized through farmer-to-farmer peer networking was instrumental in shifting production models towards agroecology and that agroecological certification provided both an opportunity and mechanism for farmers to assess their economic and agroecological performance each year. However, working primarily with pen and paper forms, the farmers found the process of certification cumbersome and labor intensive, not only for farm households but also for their network coordinators. Data analysis lagged, and participants in several workshops commented that the agroecological certification process did not fully monitor the wide range of values that were important to the organizations involved, including gender equity and the preservation of biocultural heritage.

Our research team was subsequently invited to meet with a mutual support network of PGS organizations working across several regions in Latin America. These included, in addition to CEPAGRO and Centro Vianei, Tijtoca Nemiliztli (Mexico), the Movement for Social and Solidarity Economy (Ecuador), the Association for Organic Producers (Paraguay), the Centre for Alternative and Popular Technologies (Brazil), the Foundation for Socioeconomic Development and Environmental Restoration (El Salvador), and Mecenas de Vida (Brazil). An issue raised repeatedly by members of the PGS network (and by organic farmers) is the considerable variation found across certification frameworks and the difficulties that both farmers and their organizations have faced in developing processes for storing and analyzing production and sales records.

In building on prior results from our case studies and on qualitative fieldwork with these farming organizations, from 2018-2020, we codefined a shared research challenge: the need for new, accessible, cost-effective and farmer-driven methodologies that can effectively measure the multidimensional outcomes of agroecological management across a range of farm sizes and production systems.

The PGS network discussed whether LiteFarm, a platform developed by Dr. Zia Mehrabi while working at the Centre for Sustainable Food Systems (CSFS) at the University of British Columbia (UBC) Farm from 2017-2019, through a farmer-centered participatory design process with Canadian organic and diversified farmers, researchers and technology experts, could be used to help address the challenges faced by the PGS network - specifically, to facilitate farmer-centered and easily accessible 
methods for agroecological certification and communication. Briefly, LiteFarm is a community-led, not-for-profit, digital platform joining farmers and scientists together for the participatory assessment of social, environmental and economic outputs of farming systems (https://ubcfarm.ubc.ca/litefarm/). The platform interfaces with land stewards through a web application that allows for the consistent documentation of farming metrics, including management practices; inputs such as seeds, fertilizer, and water; field activities; harvests and yields; and financial information such as expenses and sales. The app currently generates insights, in real time, for farmers based on the collected data, including data on worker satisfaction and labor quality, profits and costs of production, the number of people fed (across nutritional dimensions), fertilizer and water use efficiency, soil health, market prices (relative to other local farmers in the network), and biodiversity conservation (www.litefarm.org).

As part of the process of co-development with the PGS networks, we hosted several workshops and visited farms in the network to demonstrate, train, pilot, gather feedback, and refine the application with the ultimate goal of helping farmers within our partner organizations make more informed decisions about farm management while also developing broader-scale evidence on the performance of agroecological production systems. By integrating the wide range of social and ecological variables involved in agroecological management and grounding both research design and analysis in the experiences of farmers from multiple countries across Latin America while improving capacity and digital literacy across demographic dimensions and for underserved populations, we hope to be better positioned to assess the potential contributions of agroecology to global food security and agricultural sustainability and to identify barriers to and pathways for transition. Our transdisciplinary research team aims to chart a course for researchers to investigate how trade-offs among productive, sociocultural, economic, and/or environmental indicators might be minimized to enhance overall system sustainability while also providing tools that agroecological farmers and their organizations want to use to manage their operations. By building software focused on and adaptable to different organizational needs, we intend to help these agroecological farmers capture (some of) the benefits of the digital agricultural revolution - without ceding data sovereignty.

In 2020, our team began the process of widely testing LiteFarm in half a dozen countries across North and South America. By supporting farmers in using the application in different locales, we aim to answer calls for digital agricultural solutions to assist underserved farmers with their own day-day documentation and data-driven farming challenges while assessing sustainability outcomes associated with regional variations in particular management practices, providing an innovative methodological mechanism for tracking agroecological management outcomes across political, social, and ecological gradients. At the same time, the project supports farmer and practitioner decision-making at the farm and organizational scales. Collectively, we aim to create software that is of direct use to farmers, provide evidence of the value of agroecology, and support the development of better policies to address the many challenges facing our global food system.

\section{Ethical dimensions and data sovereignty}

In contrast to traditional (and often extractive) social science and agronomic survey work that requires lengthy and costly periods of field data collection and analysis and through which data are not always effectively returned to their owners (e.g., the farmers themselves), our project (through the LiteFarm platform) enables data and multiple insights to be made immediately and freely available to farmers. The project also provides the data in suitably anonymized form with farmers' explicit consent (which can be withdrawn electronically at any time) to their participatory certification network coordinators, who can then develop their own regionally specific 
analyses. In addition, because the platform stores data entered over time, data collection for agroecological monitoring will be ongoing via farmer training and peer-to-peer support from the PGS network, enabling community building for scaling out agroecological transitions supported through shared data analysis and the exchange of best practices for social and ecological sustainability.

Farmers within the PGS network - and among grassroots food sovereignty movements more broadly - have expressed concern over their data sovereignty, particularly around the capture of their data by external organizations (including multinational agribusiness enterprises) to be used for commercial purposes. As the project proceeds, we are developing new protocols to ensure data sovereignty (i.e., farmer ownership, access, and control) and security in addition to those already in place. We are also continuing to work within a usercenter design framework that builds on experiential and biocultural knowledge rather than replacing it.

Consistent with LiteFarm's privacy and confidentiality policy (UBC Behavioral Ethics Review Board Certificate \# H17-03121), the project partners have also agreed to make anonymized data from LiteFarm available for noncommercial academic research on sustainable food systems (farmers must opt in and can opt out at any time). Copies of nonpublic releases of anonymized data can be shared with academic researchers for noncommercial research purposes under time-limited and confidential single-use licenses. The team will rigorously evaluate every project proposal prepared to ensure that data are used effectively to advance knowledge on sustainable food systems, support farmers in making sustainable management decisions, impact public policy to benefit farmers and workers, and advance agroecology.

\section{Conclusion}

In conclusion, it remains to be seen whether a bottom-up digital agriculture solution for scaling agroecology can significantly shift power dynamics within the food system. However, we suggest that this project, which may be the world's first "grand experiment" in digital agroecology across a broad range of geographies, will provide early insights into whether and to what extent an open-source and open-access model for digital agroecology can create new pathways through which farmer organizations can design and adapt locally relevant solutions to challenges facing their own food systems while building on culturally specific indicators and certification frameworks. The collaboration outlined here provides an opportunity to follow these questions while adapting digital technology in real time to encompass and respect the core elements and praxis of agroecology: equity and justice, transparency, participation, and the co-construction of knowledge.

\section{Acknowledgement}

This manuscript summarizes the authors' intended contribution at the Workshop on Challenges for Agroecology Development for the Building of Sustainable Agri-Food Systems (CRP), which was due to take place at the Faculty of Agricultural Sciences, University of Chile, Santiago de Chile, on 11-13 November 2019, and which was sponsored by the OECD Co-operative Research Programme: Biological Resource Management for Sustainable Agricultural Systems. Although due to the circumstances the workshop did not take place as a physical meeting, contributions intended to be supported by the OECD CRP are published in this Thematic Issue.

\section{Disclaimer}

The opinions expressed and arguments employed in this manuscript are the sole responsibility of the authors and do not necessarily reflect those of the OECD or of the governments of its Member countries.

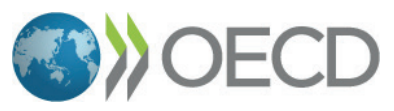




\title{
Resumen
}

\begin{abstract}
H. Wittman, D. James, y Z. Mehrabi. 2020. Fomento de la soberanía alimentaria a través de la agroecología digital. J. Agric. Nat. Resour. 235-248. La agroecología, como ciencia, práctica y movimiento social, se ha planteado como una vía para revitalizar los sistemas alimentarios mundiales a través de una transición hacia la justicia social y ecológica. Los sistemas agroecológicos y diversificados varían ampliamente a nivel mundial, el cual dificulta su caracterización a través de evaluaciones agronómicas tradicionales que se enfocan en los ingresos y el rendimiento, invisibilizando otras dimensiones socioecológicas, como el bienestar de los agricultores y trabajadores, la diversidad alimentaria, los impactos ambientales y la conservación de la biodiversidad. En respuesta, proponemos un camino para el monitoreo y evaluación digital de prácticas agroecológicas que visibiliza y respeta contextos diversos y mejora las dinámicas de poder al centrarse en la agencia y el conocimiento biocultural de diversos agricultores y comunidades. Describimos una colaboración entre la universidad y un red de agroecológica en Latino América trabajando con sistemas participativas de garantía, con el objetivo de desarrollar una herramienta digital de código abierto, de acceso abierto y definido por agricultores para el monitoreo y la certificación agroecológica. El equipo de investigación, compuesto de agricultores y científicos, tiene como objetivo trazar un curso para que los investigadores investiguen cómo se pueden minimizar las compensaciones entre los indicadores productivos, socioculturales, económicos y/o ambientales para mejorar la sostenibilidad general del sistema en diversos contextos a nivel mundial y, al mismo tiempo, proporcionar herramientas de uso para agricultores agroecológicos y sus organizaciones, que luego pueden capturar de manera autónoma (algunos de) los beneficios de la revolución agrícola digital sin ceder la soberanía.
\end{abstract}

Palabras clave: Ciencia ciudadana, ciencia de datos, digitalización, investigación acción participativa, sistemas alimentarios sostenibles, transición agroecológica.

\section{References}

AGRIS. N.d. The Agris Handbook on the Agricultural Integrated Survey. Retrieved from http:// gsars.org/en/agris-handbook-on-the-agricultural-integrated-survey/

Altieri, M. (1995). Agroecology: The Science of Sustainable Agriculture. Boulder, CO: Westview Press.

Astier, M., García-Barrios, L., Galván-Miyoshi, Y., González-Esquivel, C.E., \& Masera, O.R. (2012). Assessing the Sustainability of Small Farmer Natural Resource Management Systems. A Critical Analysis of the MESMIS Program (1995-2010). Ecology and Society 17(25). doi: 10.5751/ES-04910-170325

Bezner Kerr, R., Kangmennaang, J., Dakishoni, L., Nyantakyi-Frimpong, H., Lupafya, E., Shumba, L., Msachi, R., Boateng, G.O., Snapp, S.S., Chi- taya, A., Maona, E., Gondwe, T., Nkhonjera, P., $\&$ Luginaah, I. (2019). Participatory agroecological research on climate change adaptation improves smallholder farmer household food security and dietary diversity in Malawi. Agriculture, Ecosystems \& Environment 279:109-121. doi: 10.1016/j.agee.2019.04.004

Bowness, E., \& Wittman, H. (2020). Bringing the city to the country? Responsibility, privilege and urban agrarianism in Metro Vancouver. Journal of Peasant Studies 4:1-26. doi: 10.1016/j. jrurstud.2017.03.007

Brem-Wilson, J. (2015). Towards food sovereignty: interrogating peasant voice in the United Nations Committee on World Food Security. Journal of Peasant Studies 42:73-95. doi: 10.1080/03066150.2014.968143

D’Annolfo, R., Gemmill-Herren, B., Graeub, B., 
\& Garibaldi, L.A. (2017). A Review of Social and Economic Performance of Agroecology. International Journal of Agricultural Sustainability 15(6):632-644. doi: 10.1080/14735903.2017.1398123

Duru, M., O. Therond \& M. Fares. (2015). Designing Agroecological Transitions; A Review. Agronomy for Sustainable Development, 35(4):123757. doi: 10.1007/s13593-015-0318-x

EAT-Lancet. (2019). Food Planet Health: Healthy Diets from Sustainable Food Systems. EAT-Lancet Commission.

FAO. (2015). World Programme for the Census of Agriculture 2020: Volume 1 - Programme, concepts and definitions. Food and Agriculture Organization of the United Nations, Rome.

FAO. (2018a). Scaling Up Agroecology Initiative: Transforming Food and Agricultural Systems in Support of the SDGs. Food and Agriculture Organization of the United Nations, Rome.

FAO. (2018b). The 10 Elements of Agroecology: Guiding the Transition to Sustainable Food and Agricultural Systems. Food and Agriculture Organization of the United Nations, Rome.

FAO. (2019). Tool for agroecology performance evaluation: Process of Process of development and guidelines for application: Test version. Rome, FAO. Retrieved from http://www.fao.org/ policy-support/tools-and-publications/resourcesdetails/en/c/1257355/

FNIGC. (2014). Ownership, Control, Access and Possession (OCAPTM): The Path to First Nations Information Governance. First Nations Information Governance Centre, Ottawa.

Foley, J.A., Ramankutty, N., Brauman, K.A., Cassidy, E.S., Gerber, J.S., Johnston, M., Mueller, N.D., O'Connell, C., Ray, D.K., West, P.C., Balzer, C., Bennett, E.M., Carpenter, S.R., Hill, J., Monfreda, C., Polasky, S., Rockström, J., Sheehan, J., Siebert, S., Tilman, D., \& Zaks, D.P.M. (2012). Solutions for a cultivated planet. $\mathrm{Na}$ ture, 478:337-342. doi: 10.1038/nature10452

Gliessman, S. (2016). Transforming Food Systems with Agroecology. Agroecology and Sustainable Food Systems 40(3):187-89. doi: 10.1080/21683565.2015.1130765
Grenz, J., Mainiero, R., Schoch, M., Sereke, F., Stadler, S., Thalmann, C., \& Wyss, R. (2016). "RISE 3.0 Manual". Bern University of Applied Sciences. Retrieved from www.rise.hafl.bfh.ch

Guerra, J., Blesh, J., Schmitt Filho, A.L., \& Wittman, H. (2017). Pathways to agroecological management through mediated markets in Santa Catarina, Brazil. Elementa: Science of the Anthropocene, 5:67. doi: 10.1525/journal. elementa. 248

Hendrickson, M.K., \& James, H.S. (2005). The ethics of constrained choice: how the industrialization of agriculture impacts farming and farmer behavior. Journal of Agricultural and Environmental Ethics, 18:269-291. doi: 10.1007/ s10806-005-0631-5

Hilbeck, A., \& Tisselli, E. (2020). The emerging issue of "digitalization" in agriculture. In H. Herren, B. Haerlin and IAASTD+10 Advisory Group, Transformation of Our Food Systems: The Making of a Paradigm Shift. Berlin and Zurich: Foundation on Future Farming and Biovision.

HLPE. (2019). Agroecological and Other Innovative Approaches for Sustainable Agriculture and Food Systems That Enhance Food Security and Nutrition. Rome.

Howard, J. (2019). Interpreting the Growing Field of On-Farm Data. Retrieved from https://cals.ncsu. edu/crop-and-soil-sciences/news/interpretingthe-growing-field-of-on-farm-data/

IFOAM. (2018). IFOAM Policy Brief on How Governments can recognize and support participatory guarantee systems (PGS). IFOAM Organics International.

IFOAM. (2019). PGS Statistics Map. Retrieved from https://archive.ifoam.bio/en/pgs-maps

Isaac, M.E., and Martin, A.R. (2019). Accumulating crop functional trait data with citizen science. Scientific Reports, 9:15715. doi: 10.1038/ s41598-019-51927-x

Kimura, A.H., \& Kinchy, A. (2019). Science By the People: Participation, Power, and Politics of Environmental Knowledge. Rutgers University Press, New Brunswick, NJ.

Kremen, C., Iles, A., \& Bacon, C. (2012). Diversified Farming Systems: An Agroecological, Systems- 
Based Alternative to Modern Industrial Agriculture. Ecology and Society, 17(4):44-63. doi: 10.5751/ES-05103-170444

Kukutai, T., \& Taylor, J. (Eds.). (2016). Indigenous Data Sovereignty: Towards an Agenda. ANU Press, Acton, Australia.

Magliocca, N.R., Ellis, E.C., Allington, G.R.H., de Bremond, A., Dell'Angelo, J., Mertz, O., Messerli, P., Meyfroidt, P., Seppelt, R., \& Verburg, P.H. (2018). Closing global knowledge gaps: Producing generalized knowledge from case studies of social-ecological systems. Global Environmental Change, 50:1-14. doi: 10.1016/j. gloenvcha.2018.03.003

Mehrabi, Z., McDowell, M.J., Ricciardi, V., Levers, C., Martinez, J.D., Mehrabi, N., Wittman, H., Ramankutty, N., \& Jarvis, A. (2020). The global divide in data-driven farming. Nature Sustainability, 1-7. doi: 10.1038/s41893-020-00631-0

Mendez, V.E., Bacon, C.M., Cohen, R., \& Gliessman, S.R. (2015). Agroecology: A Transdisciplinary, Participatory and Action-Oriented Approach. Edited by C.A. Edwards. Boca Raton: CRC Press.

Mendez, V.E., Caswell, M., Gliessman, S., \& Cohen, R. (2017). Integrating Agroecology and Participatory Action Research (PAR): Lessons from Central America. Sustainability, 9:705. doi: 10.1080/21683565.2014.951459

Mitchell, C. (2018). Technology Hope for African Farmers. Financial Times. Retrieved from https://www.ft.com/content/3316885c-b07d11e8-87e0-d84e0d934341

Mooney, P. (2018). What's cooking for climate change? Techno-fixing dinner for 10 billion. Bulletin of the Atomic Scientists, 74:390-396. doi: 10.1080/00963402.2018.1533214

Nelson, E., Gómez Tovar, L., Schwentesius Rindermann, R., \& Gómez Cruz, M.A. (2009). Participatory organic certification in Mexico: an alternative approach to maintaining the integrity of the organic label. Agriculture and Human Values, 27:227-237. doi: 10.1007/s10460-009-9205-x

Nyéléni Forum for Food Sovereignty. (2019). The digitalization of the food system. Nyéléni Newsletter No. 37. Retrieved from https://nyeleni.org/
DOWNLOADS/newsletters/Nyeleni_Newsletter_Num_37_EN.pdf

Perfecto, I., \& Vandermeer, J.H. (2010). The agroecological matrix as alternative to the landsparing/agriculture intensification model. Proceedings of the National Academy of Sciences, 107:5786-5791. doi: 10.1073/pnas.0905455107

Pimbert, M. (Ed). (2018). Food Sovereignty, Agroecology and Biocultural Diversity: Constructing and Contesting Knowledge. Routledge/Earthscan, pp. 259-321.

Pretty, J., Benton, T.G., Bharucha, Z.P., Dicks, L.V., Flora, C.B., Godfray, H.C.J., Goulson, D., Hartley, S., Lampkin, N., Morris, C., Pierzynski, G., Prasad, P.V.V., Reganold, J., Rockström, J., Smith, P., Thorne, P., \& Wratten, S. (2018). Global assessment of agricultural system redesign for sustainable intensification. Nature Sustainability, 1:441-446. doi: 10.1038/nature25785

Pretty, J., Attwood, S., Bawden, R., van den Berg, H., Bharucha, Z.P., Dixon, J., Flora, C.B., Gallagher, K., Genskow, K., Hartley, S.E., Ketelaar, J.W., Kiara, J.K., Kumar, V., Lu, Y., MacMillan, T., Maréchal, A., Morales-Abubakar, A.L., Noble, A., Prasad, P.V.V., Rametsteiner, E., Reganold, J., Ricks, J.I., Rockström, J., Saito, O., Thorne, P., Wang, S., Wittman, H., Winter, M., $\&$ Yang, P. (2020). Assessment of the growth in social groups for sustainable agriculture and land management. Global Sustainability, 3:1-16. doi: 10.1017/sus.2020.19

Ramankutty, N., Ricciardi, V., Mehrabi, Z., \& Seufert, V. (2019). Trade-offs in the performance of alternative farming systems. Agricultural Economics, 50:97-105. doi: 10.1016/j.foodpol.2010.04.007

Ricciardi, V., Ramankutty, N., Mehrabi, Z., Jarvis, L., \& Chookolingo, B. (2018). How much of the world's food do smallholders produce? Global Food Security, 17:64-72. doi: 10.1016/j.gfs.2018.05.002

Ricciardi, V., Wane, A., Sidhu, B.S., Goode, C., Solomon, D., McCullough, E., Diekmann, F., Porciello, J., Jain, M., Randall, N., \& Mehrabi, Z. (2020). A scoping review of research funding for small-scale farmers in water scarce regions. $\mathrm{Na}$ ture Sustainability, 1-11. doi: 10.1038/s41893020-00623-0 
Rotz, S., Duncan, E., Small, M., Botschner, J., Dara, R., Mosby, I., Reed, M., \& Fraser, E.D.G. (2019). The Politics of Digital Agricultural Technologies: A Preliminary Review. Sociologia Ruralis, 59:203-229. doi: 10.1177/2053951714559253

Ruiz-Almeida, A., \& Rivera-Ferre, M.G. (2019). Internationally-based indicators to measure Agri-food systems sustainability using food sovereignty as a conceptual framework. Food Security, 1-17. doi: 10.1007/s12571-019-00964-5

Ryan, S.F., Adamson, N.L., Aktipis, A., Andersen, L.K., Austin, R., Barnes, L., Beasley, M.R., Bedell, K.D., Briggs, S., Chapman, B., Cooper, C.B., Corn, J.O., Creamer, N.G., Delborne, J.A., Domenico, P., Driscoll, E., Goodwin, J., Hjarding, A., Hulbert, J.M., Isard, S., Just, M.G., Kar Gupta, K., Lopez-Uribe, M.M., O’Sullivan, J., Landis, E.A., Madden, A.A., McKenney, E.A., Nichols, L.M., Reading, B.J., Russell, S., Sengupta, N., Shapiro, L.R., Shell, L.K., Sheard, J.K., Shoemaker, D.D., Sorger, D.M., Starling, C., Thakur, S., Vatsavai, R.R., Weinstein, M., Winfrey, P., \& Dunn, R.R. (2018). The role of citizen science in addressing grand challenges in food and agriculture research. Proceedings of the Royal Society B: Biological Sciences, 285:20181977. doi: 10.1098/rspb.2018.1977

Seufert, V., N. Ramankutty, \& T. Mayerhofer. (2017). What is this thing called organic? - How organic farming is codified in regulations. Journal of Food Policy, 68:10-20. doi: 10.1016/j.foodpol.2016.12.009

Shibusawa. 2001. Precision Farming Approaches for Small Scale Farms. IFAC Proceedings Volume, 34: 22-27.
Srinivasan, A. (1999). Precision Farming in Asia: Progress and Prospects. Proceedings of the Fourth International Conference on Precision Agriculture. Retrieved from https://doi. org/10.2134/1999.precisionagproc4.c61

Steinke, J., van Etten, J., \& Zelan, P.M. (2017). The accuracy of farmer-generated data in an agricultural citizen science methodology. Agronomy for Sustainable Development, 37(32). doi: 10.1007/ s13593-017-0441-y

Trendov, N.M., Varas, S., \& Zeng, M. (2019). Digital Technologies in Agriculture and Rural Areas: Status Report. Food and Agriculture Organization of the United Nations, Rome.

van Etten, J., de Sousa, K., Aguilar, A., Barrios, M., Coto, A., Dell'Acqua, M.,... Steinke, J. (2019). Crop variety management for climate adaptation supported by citizen science. Proceedings of the National Academy of Sciences, 116(10):41944199. doi: 10.1073/pnas. 1813720116

Van Loon, J., Speratti, A.B., Gabarra, L., and Govaerts, B. (2018). Precision for Smallholder Farmers: A Small-Scale-Tailored Variable Rate Fertilizer Application Kit. Agriculture, 8(4):48.

Wittman, H., Chappell, M.J., Abson, D.J., Bezner Kerr, R., Blesh, J., Hanspach, J., Perfecto, I., \& Fischer, J. (2017). A Social-Ecological Perspective on Harmonizing Food Security and Biodiversity Conservation. Regional Environmental Change, 17(5):12911301. doi: 10.1007/s10113-016-1045-9

Wittman, H., \& Blesh, J. (2017). Food Sovereignty and Fome Zero: Connecting Public Food Procurement Programmes to Sustainable Rural Development in Brazil. Journal of Agrarian Change, 17(1):81-105. doi: 10.1111/joac. 12131 